\title{
Frequency of Candida species isolated from the Oral Cavity of HIV- Infected Patients referring to Behavioral disease Counseling Center of Isfahan in 2017-2018
}

\author{
Heidarian Asgha ${ }^{1}$,Parvin Dehghan ${ }^{2}$, Mostafa Chadeganipour ${ }^{3}$, Katayon Tayeri ${ }^{4}$ \\ 1.MS student of Medical mycology, Department of Mycology and Parasitology, Isfahan University of Medical Sciences . \\ 2. PhD of Medical Mycology, Department of Mycology and Parasitology, Isfahan University of Medical Sciences .ORCID \\ CD:0000-0002-0000-6643 \\ 3. PhD of Medical Mycology, Department of Mycology and Parasitology, Isfahan University of Medical Sciences \\ 4.Infectious Diseases specialist and fellowship of AIDS Research Center, Tehran University of Medical Sciences.
}

\begin{abstract}
Background and Aim: patients infected with HIV are susceptible to opportunistic infections such as candidiasis. In normal individuals, Candida spp. exist as normal flora of the mucous membranes. In this study we compared the frequencies of different species of Candida between HIV infected patients receiving anti-retroviral therapy (ART) and normal individuals .

Materials and Methods: This case- control study included 60 HIV positive patients receiving antiviral therapy as our case group and 60 normal individuals as control group. Oral samples were prepared by two wet swabs and cultured on Sabouraud dextrose agar. Colonies grown on the culture medium were identified by phenotyping and molecular (PCR) methods at two different temperatures.

Results: Candida species were isolated from the oral mucosa of $68.3 \%$ of HIV positive patients and $53.3 \%$ of normal individuals. Rate of colonization of oral cavity by candida showed no significant relationships with the variable parameters of TCD4+ $(\mathrm{P}=0.12)$, viral load $(\mathrm{P}=0.24)$, and duration of HIV infection $(\mathrm{P}=0.92)$, but it had significant relationships with brushing $(\mathrm{P}=0.001)$, smoking $(\mathrm{P}=0.043)$ and drug abuse $(\mathrm{P}=0.002)$.

Conclusion: The result showed an increased shift of the yeast colonization from C.albicans to non- albicans species in HIV-infected subjects. Considering the susceptibility of this group to opportunistic infections such as candidiasis, regular and periodic monitoring of these patients is necessary. Tooth brushing, discontinuation of cigarette smoking and drug abuse, together with oral hygiene are recommended.
\end{abstract}

Keywords: AIDS, HIV, Candida, Viral load, C. albicans

Recived: feb3,2019 Accept: Aug24.2019

How to cite the article: Elham Razani, Davood Bashash. Frequency of Candida species isolated from the Oral Cavity of HIV-Infected Patients referring to Behavioral disease Counseling Center of Isfahan in 2017-2018. SJKU 2019; 24 (5): 30-41

Copyright (C) 2018 the Author (s). Published by Kurdistan University of Medical Sciences. This is an open access article distributed under the terms of the Creative Commons Attribution-Non Commercial License 4.0 (CCBYNC), where it is permissible to download, share, remix, transform, and buildup the work provided it is properly cited. The work cannot be used commercially without permission from the journal. 


\title{
بررسى فراوانى كونههاى كانديدايى جدا شده از دهان افراد مبتلا به HIV مراجعه كننده به

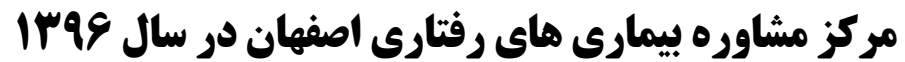

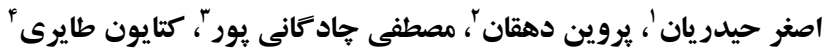

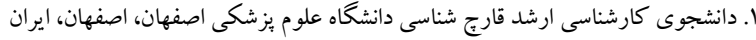

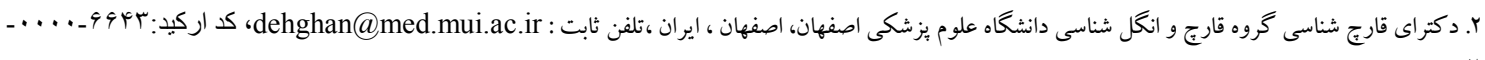 \\ ......... \\ r.r. كتراى قارج شناسى گروه قارج و انكل شناسى دانشكاه علوم يزشكى اصفهان، اصفهان، ايران

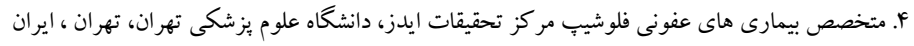

جكيuه

زمينه و هدف: در بيماران آلوده به اج آى وى زمينه براى ايجـاد عفونـت هـاى فرصـت طلـب ازجمله كانديــيازيس فـراهم مى شود. كانديدا در حالت طبيعى به صورت فلور نرمال در مخاطات يافت مى شود. در ايـن مطالعه، فراوانسى انـواع كونـه هـاى كانديدا در دهان بيماران HIV مثبت تحت درمان ضد ويروسى در مقايسه با گروه شاهد مورد بررسى قرار مى گيرد. روش بروسى: در مطالعه مورد - شاهدى حاضر، از ·9 بيمار مبتلا به HIV كه تحت درمان ضد ويروسى بـوده و يـك كروه

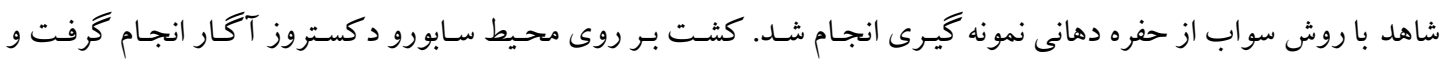
كلنىهاى رشد كرده با روش فنوتييكى، مولكولى (PCR) و رشد در دماهاى مختلف شناسايى شدند.

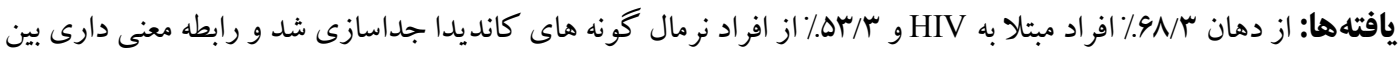

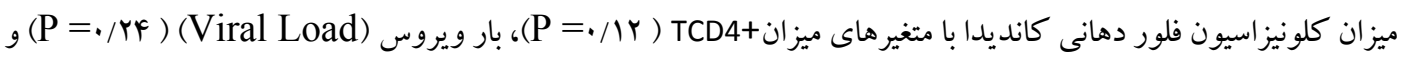

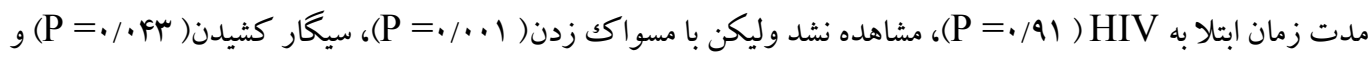
مصرف مواد مخدر (P= (P = ارتباط معنى دار مشاهده شد.

نتيجه كيرى: اين بررسى نشان داد كه در بيماران ايدزى يك شيفت و افزايشى به كونه هاى غير آلبكنسى ديده مى شـود و بـا

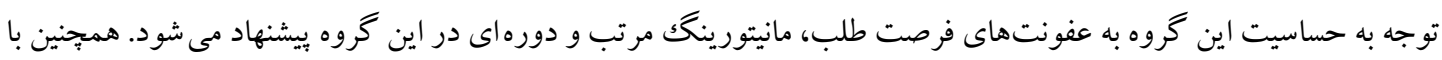
توجه به نقش مسو اكك زدن و عدم مصرف مواد مخدر و سيگار در كاهش فلور كانديدايى، رعايت بهداشت دهان در اين گرروه تو صيه مى شود.

كليدوازه ها: HIV، كانديدا، كانديدا آلبيكنس، بار ويروس (Viral Load) وصول مقاله:9V/M/IF 
بيماران كونه هاى مخمرى جدا كردند كه •ه \% آن ها

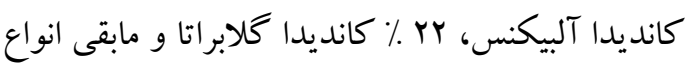

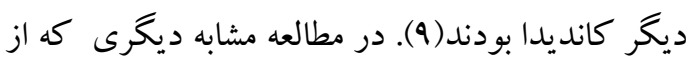
نمونه دهانى •له بيمار آلوده به ويروس HIV انجام شد،

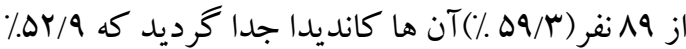

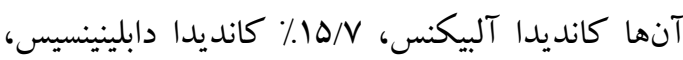

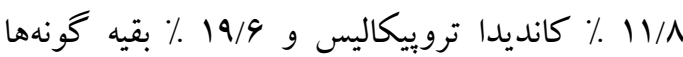
تشخيص داده شد(•(1). در ايتاليا در مطالعهاى بر روى

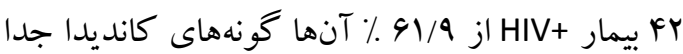

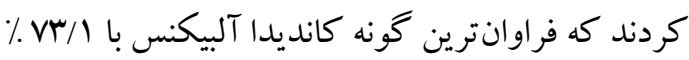
بود(1) و از تعداد VD بيمار مبتلا به ايدز، در هندوستان در سٓ/90/\% آنان مخمّر كانديدا از دهانشان جدا كردند در حالى كه در گروه كنترل اين مقدار اس/FYK بود و فراوان ترين گونه جداشده كانديدا آليكنس به ميزان

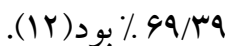

با توجه به اهميت براكندگى گُونهاى متفاوت كانديدا و تفاوت مقاومتهاى دارويى در گونههاى متفاوت بهات كانديدا، هدف اصلى در تحقيق حاضر ارزيابى ميزان و نوع فلور دهانى كانديدايى در بيماران مبتلا به ويروس تحت درمان ضد ويروسى جهت كمكك به HIV بزشكان درمانكر اين بيماران است.

\section{روش بروسى}

اين مطالعه از نوع مورد - شاهدى بوده و معيار ورود در مطالعه بيماران HIV مثبت تحت درمان ضد ويروسى مىباشند كه بيمارى آنها طبق يروتكل كشورى با

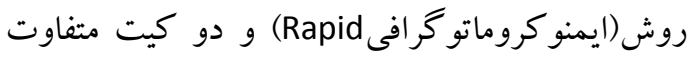

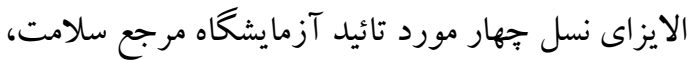
به اثبات رسيده است(r|). جهت دريافت مراقبت هاى دورهاى و درمان به مركز مشاوره بيمارىهاى رفتارى
مقلدمه

كانديدا يكى از قارجهاى مخمرى فرصت طلب است كه جزو فلور نرمال مخاطات در بدن بوده و در دهان و

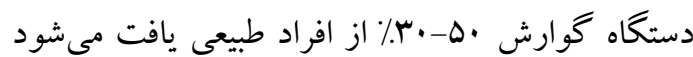
كه البته در بيماران تحت مراقبت يزشكى اين مقدار

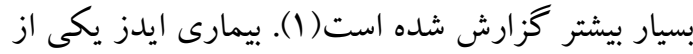
مهمترين بيمارىهاى نقص سيستم ايمنى سلولى است كه توسط ويروس HIV ايجاد شده و با توجه به تهاجم اين ويروس به سلولهاى لنفوسيت + CD4 و از بين بردن اين سلولها كه به نوعى نقش فرماندهى سيستم دفاع سلولى را بر عهده دارند، زمينه را براى ايجاد بيمارىهاى عفونى فرصت طلب از جمله كانديديازيس فراهم مى كند. به طورى كه حدود هو ٪ از افراد مبتلا به HIV حداقل يككبار در طول بيمارى به ضايعات دهانى ناشى از اين مخمر مبتلا مىشوند(Y). ضايعات دهانى معمولاً اولين علامت بروز يافته در بيماران مبتلا

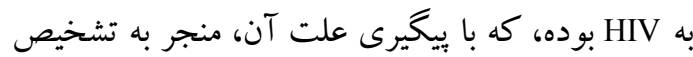
ايدز در آن ها شده است و شايعترين ضايعه در بيماران

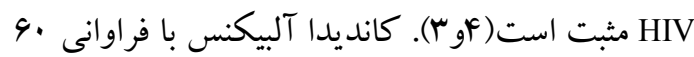
تا •مدر صد به عنوان شايع ترين گُونه جدا شده از دهان

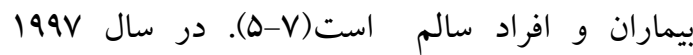
و و همكاران درگزارشى مربوط به بيمارى كانديديازيس در افراد مبتلا به ايدز به گونه جديدى از كانديدا به نام كانديدا دابلينينسيس اشاره نموده و در مورد اين گونه جديد در افراد ايدزى مى بردازد كه از نظر فنوتييى خيلى شبيه كانديدا آليكنس است، ولى از نظر زنو تييى متفاوت بوده و از نظر شدت بيمارىزايى و مقاومت به داروى فلوكونازول حائز اهميت بيشترى

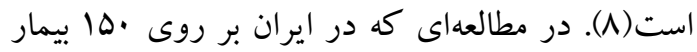

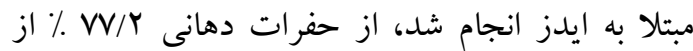




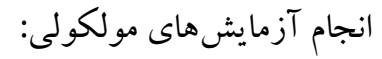

استخراج DNA: جهت انجام آزمايش ملكولى بر روى

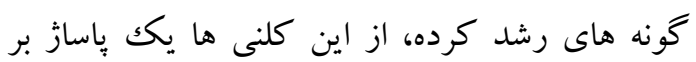

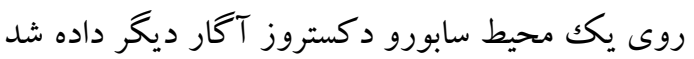

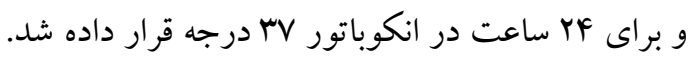
از كلنهاى رشد كرده به اندازه يكك لوب بِ بر درون يك ميكرو تيوب r ميلى ليترى حاوى •ه ميكروليتر

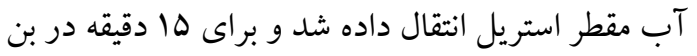

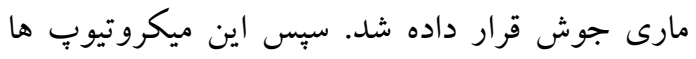

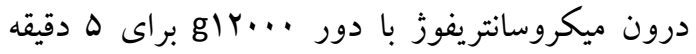
سانتريفوز شد و از محلول رويى جهت انجام آزمايشهاى مولكولى به يك ميكروتيوٍ استريل

DNA Free انجام واكنش PCR : در مرحله اول واكنش PCR با استفاده از يرايمرهاى ITS1 و ITS4 با حجم كلى .r ميكروليتر براى يكك واكنش (10 Mastermix)

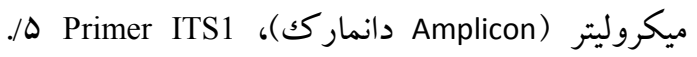
ميكروليتر با غلظت ها ييكومول،

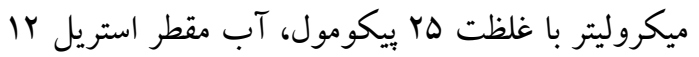

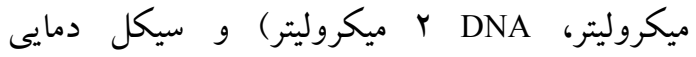

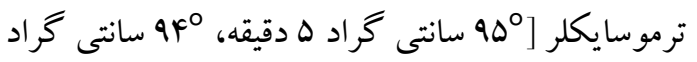

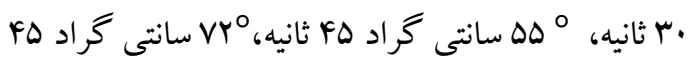
ثانيه، از دماى

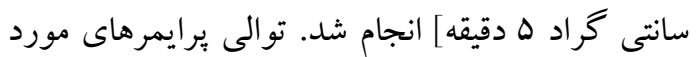
استفاده در واكنش به قرار زير است: (TGC GG3') ITS1= 5'TCC GTA GGT GAA CCT ( TAT GC3') ITS4= 5'TCC TCC GCT TAT TGA از محصول PCR در زل 1) الكتروفورز انجام

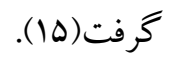

اصفهان در سال و941 مراجعه مى كردند و يكك گروه كنترل نيز شامل افراد HIV منفى كه از نظر سن و جنس كنس

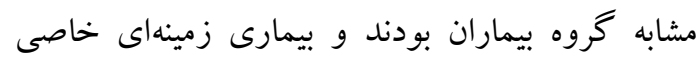
نداشتند، انتخاب شدند. حجم نمونه نيز بر اساس محاسبات آمارى انجام شده توسط مشاور آمارى ·9 نفر براى هر گروه تعيين شد.

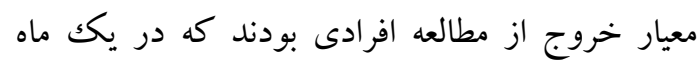

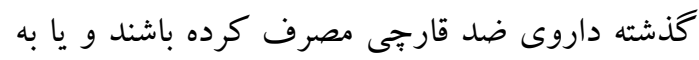
هر دليل از شركت در مطالعه انصراف دهند. در ابتدا يكك رضايتنامه بر اساس فرمت تهيه شده در كميته اخلاق دانشكاه توسط فرد داوطلب تكميل شد و رونابن اطلاعات دمو كرافيك شامل جنسيت، سن، مدت ابتلا به ايدز، مسواكك زدن، مصرف دهانشويه، مصرف سيكار، ابتلا به ديابت، مصرف مواد مخدر، نو نوع و ميزان رابطه جنسى از شخص مراجعه كنده در يكك بركه

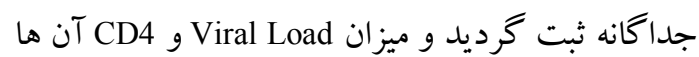
از يرونده يزشكى آن ها استخراج كرديد.

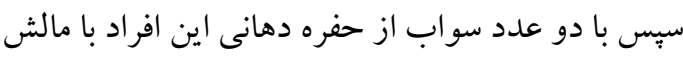
سواب به نقاط مختلف دهان به خصوص اطراف لثه و و دان

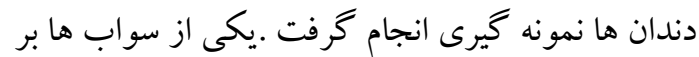

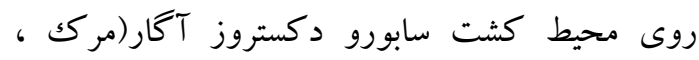
آلمان) به صورت فرشى كشت داده شد و با يكى از سواب ها يكك عدد اسمير بر روى لام تهيه شد.لام ها با بال

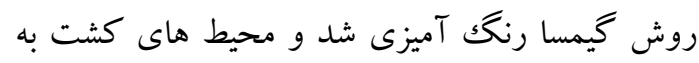

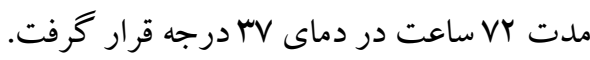
كلنى هاى رشد كرده در محيط سابورو دكستروز آكار به عنوان معيارى از ميزان و شدت كلونيزاسيون شمارش شد و بر روى يكك محيط كروم كانديدا آكار (هايمديا،

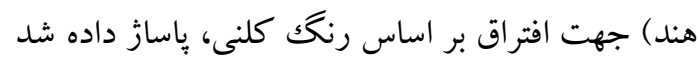
و به مدت NF ساعت در لrV درجه انكوبه شد. 
bاهر شدند(IV r... كونه آلبكنس و دابلينينسيس از كشت در دماى بr و و

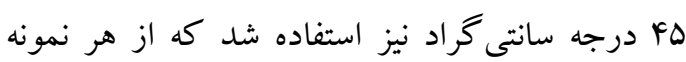
كلنى مشكو كك به اين دو گونه بر روى دوسرى محيط سابورو دكستروز آكار كشت داده شد و يكك سرى از محيطها در دماى Fr درجه و سرى ديخرى در دماى

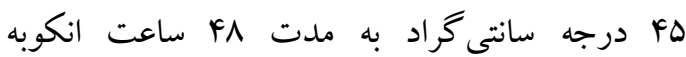

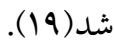
بمنظور تجزيه و تحليل؛ داده هاى دمو گرافيك بيماران و نتايج تشخيص آزمايشهاى در برنامه نرم افزارى ANOVA وارد شد و با آزمون هاى آمارى SPS 20 جهت مقايسه جند گروهى و آزمون اسبيرمن جهت بررسى همبستكى متغيرهاى كمى مورد تحليل قرار كرفت.ضمناكد اخلاق مربوط به مطالعه در دانشگاه

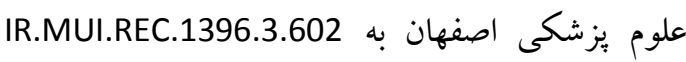
ثبت گرديده است.

\section{يافتهها}

از •و نفر بيمار HIV مثبت تحت درمان ويروس (ART) كه به اين مركز مراجعه كرده و حاضر به شركت در اين مطالعه شدند ·• نفر مرد و ·r نفر زن كه از نظر سنى در رده سنى بين ·ل تا 90 سال و بيشترين فراوانى در محدوده هFF-r سال بود. مدت زمان ابتلا به HIV در

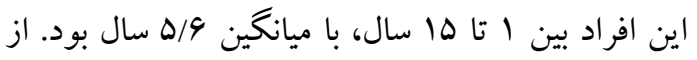

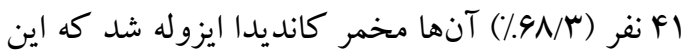
ميزان در گروه شاهد بr نفر (س/هه/\%) بود. با توجه به رنگك كلنىهاى بِاساز داده شده بر روى محيط كروم

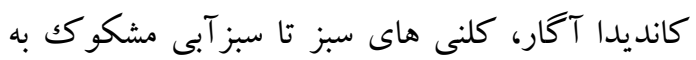
كانديدا آلبيكنس و دابلينيسيس، كلنى هاى كرم، كرم صورتى تا بنفش مشكو كى به كانديدا كلابراتا، كروزه
در مرحله بعد با روش PCR-RFLP و استفاده از آنزيم

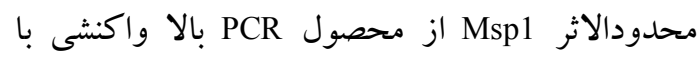
حجم ها ميكرومتر [شامل آنزيم آمريكا)، بافر آ Thermo Fisher) ميكروليتر، آب مقطر استريل ץ ميكروليتر و محصول

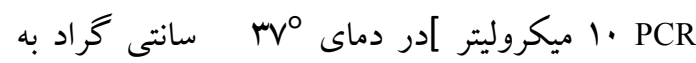
مدت ·ه دقيقه واكنش انجام شد (rا). انجام

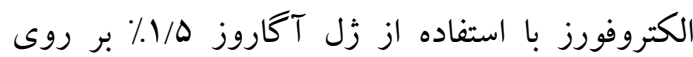
محصول واكنش PCR-RFLP انجام گرفت (19).

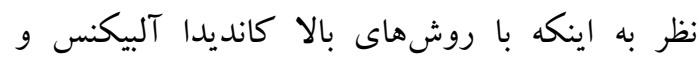
دابلينينسيس قابل افتراق نمىباشند از روش 10 براى تمايز بين اين دو گونه با حجم واكنش

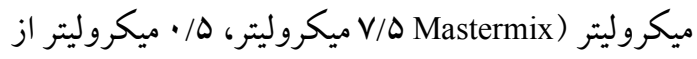

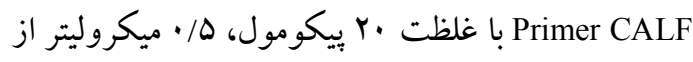

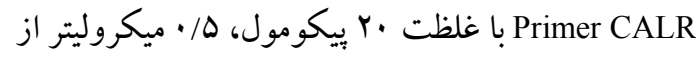

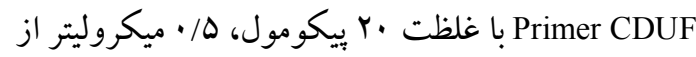
Primer CDUR با غلظت ·r ب بيكومول، آب مقطر استريل ه/ه ميكروليتر و DNA r ميكروليتر) و سيكل

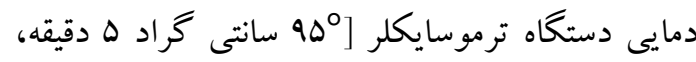

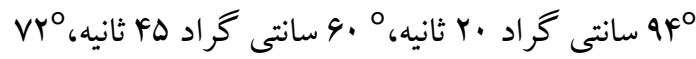
سانتى گر اد ·r ثانيه، از دماى

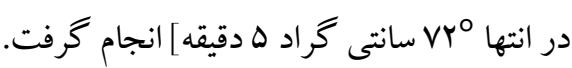
( TGGTAAGGCGGGATCGCTT-3') CALF = 5'CALR $=$ 5'-GGTCAAAGTTTGAAGATATAC(3') CDUF $=5$ '-AAACTTGTCACGAGATTATTTTT(3')

CDUR $=5$ '-AAAGTTTGAAGAATAAAATGGC(3')

جهت مشاهده باندهاى تكثير شده، از الكتروفورز با زل

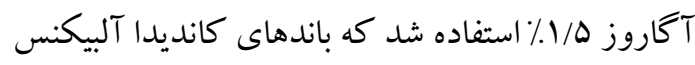
در محدوده . . bpl و كانديدا دابلينينسيس در محدوده 


\begin{tabular}{|c|c|}
\hline 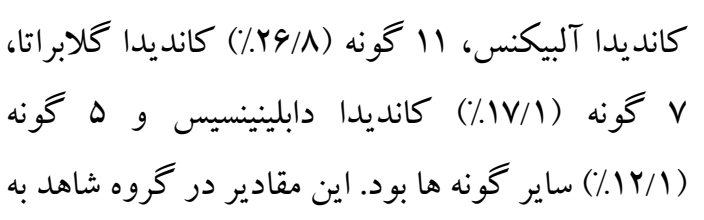 & 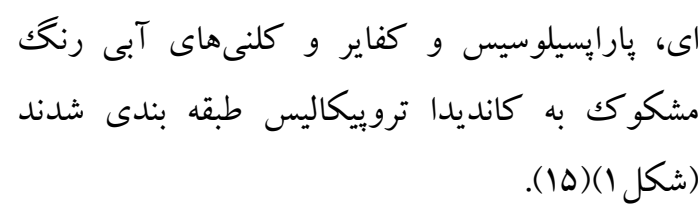 \\
\hline 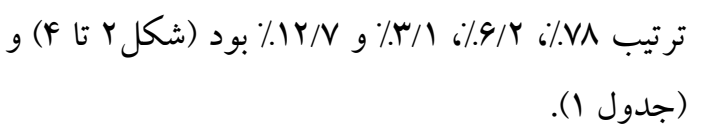 & ه بيماران HIV مث \\
\hline
\end{tabular}

\begin{tabular}{|c|c|c|}
\hline تعداد (درصد) ايزوله & 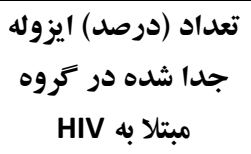 & كونه \\
\hline$(\% \mathrm{V \Lambda})$ YD & $(\% F F) 11$ & كانديدا آلبيكنس \\
\hline$(/ .9 / Y) Y$ & $(\%$ Y $9 / \wedge) 11$ & كانديدا كلابراتا \\
\hline$(/ . r / 1) 1$ & $(\% \mathrm{IV} / \mathrm{I}) \mathrm{V}$ & كانديدا دابلينينسيس \\
\hline$(\% / r / 1) 1$ & $(\% / / \Lambda) r$ & كانديدا تروييكاليس \\
\hline$(\% / r / 1) 1$ & $(\% / r / \Psi) 1$ & كانديدا كروزئى \\
\hline$(1.9 / Y) Y$ & $(/ / F / \Lambda) r$ & كانديدا كفاير \\
\hline
\end{tabular}

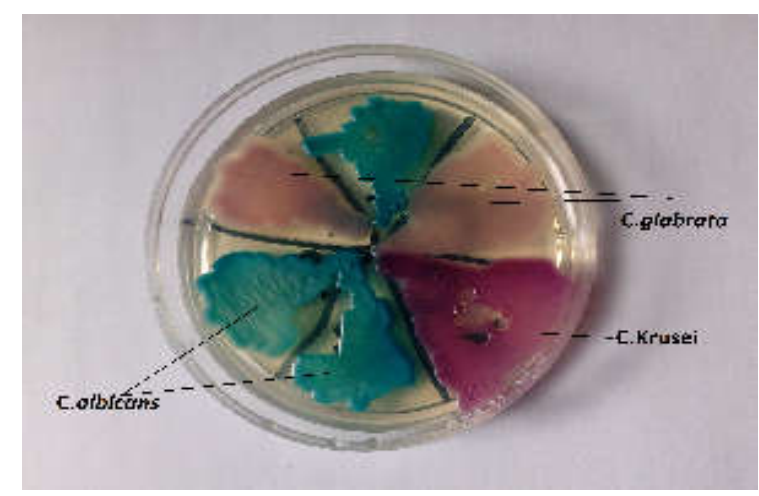

شكل ا. رنكك كلنى هاى انواع كانديداى جدا شده از دهان افراد مو رد مطالعه بر روى محيط كروم كانديدا آكار

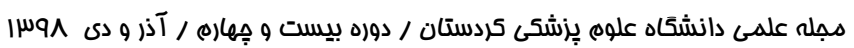




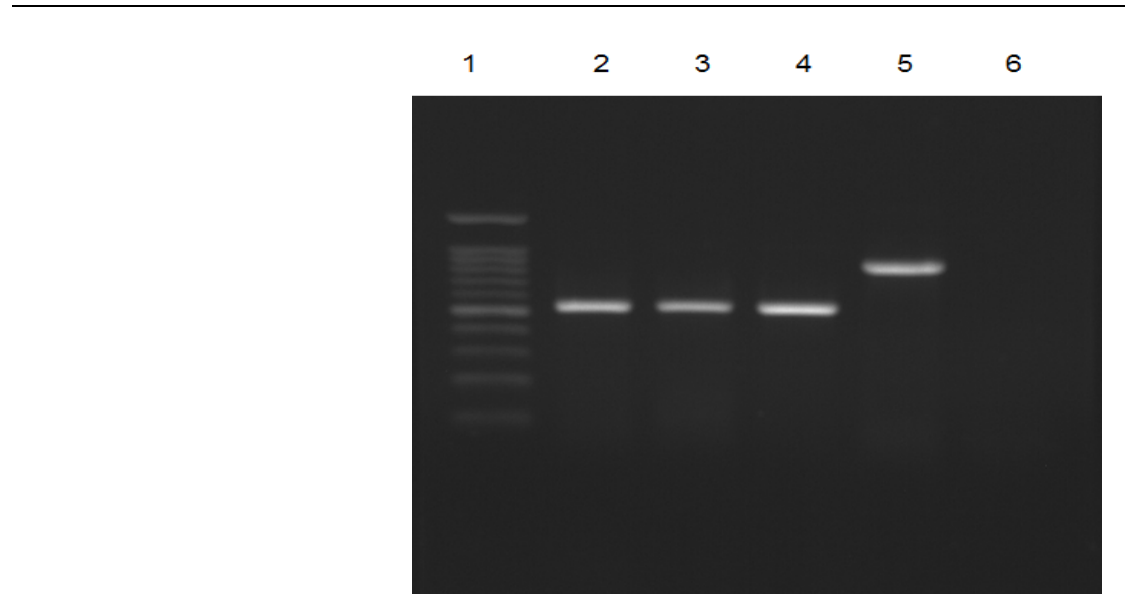

شكل r. واكنش PCR با استفاده از ير ايمرهاى ITS1 و ITS4

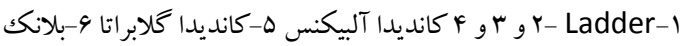

\section{$\begin{array}{lllll}1 & 2 & 3 & 4 & 5\end{array}$}

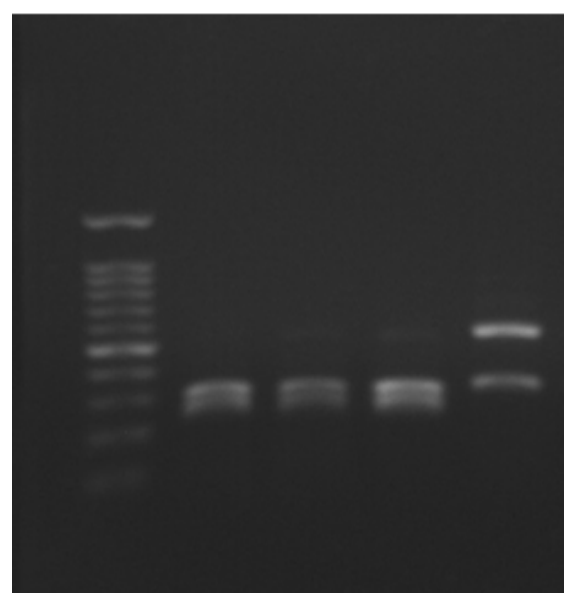

Msp1 بكل r. واكنش PCR-RFLP استفاده از آنزيم محدودالاثر

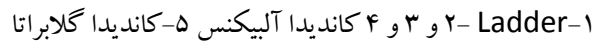

$\begin{array}{lllllllllllllll}15 & 14 & 13 & 12 & 11 & 10 & 9 & 8 & 7 & 6 & 5 & 4 & 3 & 2 & 1\end{array}$

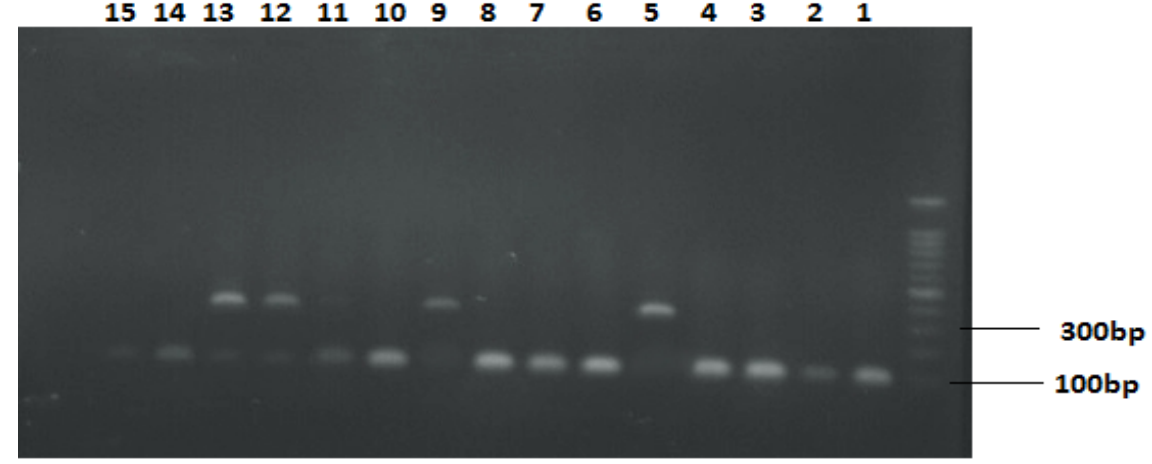

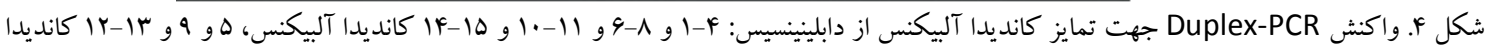
دابلينينسيس 
آلبيكنس و گلابراتا جدا شد و در گروه شاهد ميانگين

كلنى كانت سلا بود كه در يكك مورد كه بالاى .... كلنى در هيليت رشد كرده بود كلينيزاسيون توأم كانديدا آلبيكنس و كفاير مشاهده شد.

در نتيجه كشت كانديداهاى مشكوكى به كميلكس آلبيكنس/دابلينينسيس در دو دماى Fr و F F F درجه، كانديدا آلبيكنس در هر دو دما رشد كرد وليكن دور دماكن كانديدا دابلينينسيس فقط در دماى بF درجه رشد كرده بود كه نتايج به دست آمده از اين آزمايش با نتايج به دست آمده از روش Duplex-PCR تطابق داشت(شكل

$(\Delta$
از أج بيمار HIV مثبت كه داراى فلور دهانى كانديدايى

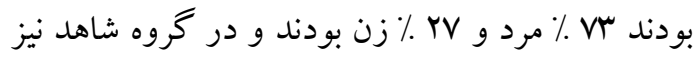

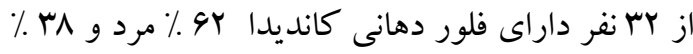
زن بودند، لذا در هر دو گروه ميزان كلونيزاسيون دهانى كانديدا در مردان بيش از زنان بوده است. هيج كدام از بيماران داراى ضايعه دهانى نبودند در لام مستقيم آنها سودو هايف مشاهده نشد در حالى كه در محيط كشت دمان تعداد كلنى قابل توجهى رشد نمود. ميانخين كلنى كانت رشد كرده در هر يليت در كروه بيماران MV كلنى بود كه در ها مورد از آن ها كه بيشتر از . . كلنى رشد كرده بود كلونيزاسيون توأم كانديدا

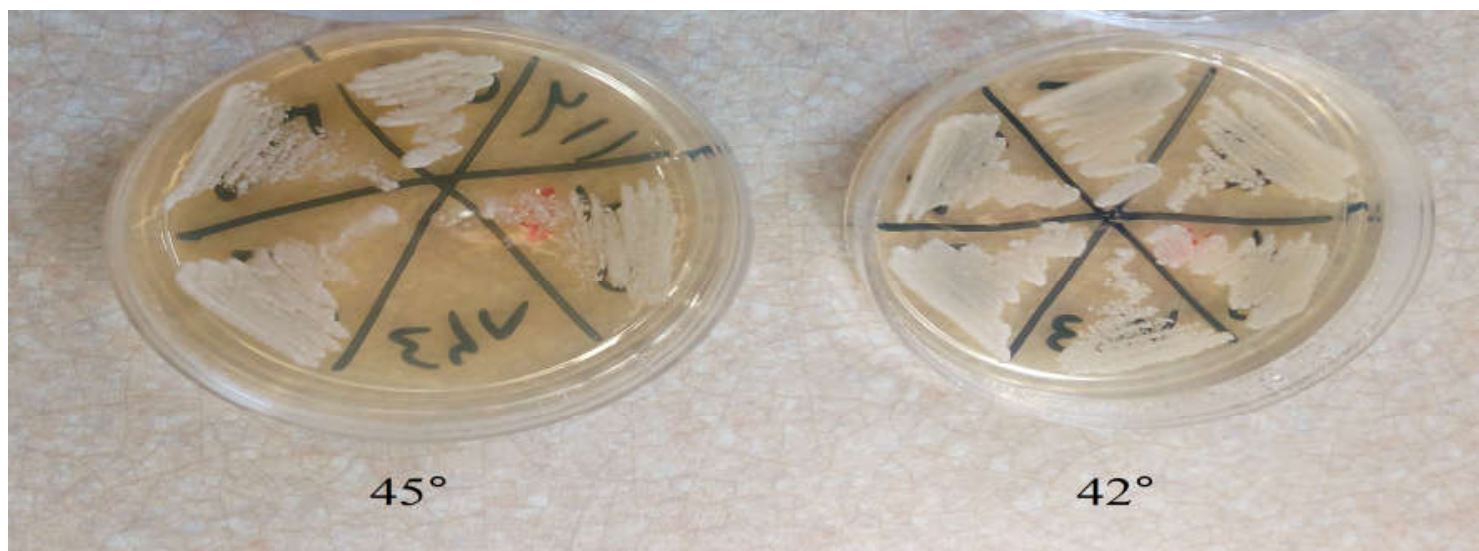

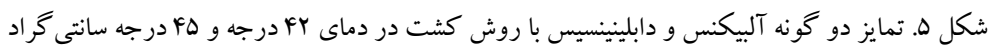

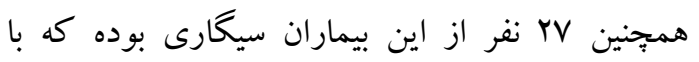

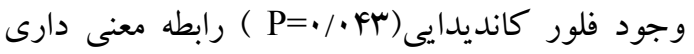
داشت fl أنفر نيز مواد مخدر مصرف مى كردند كه با

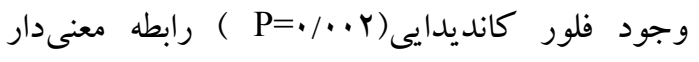

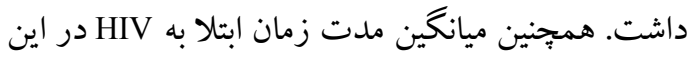
گروه 19/ه با رنج بين ا تا ها سال بود و نيمى از آنها زير F سال مدت زمان ابتلاى آنها بود و البته با ميزان

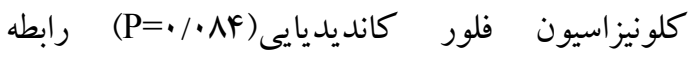
معنىدارى نداشت. با توجه به اينكه تنها 9 نفر از اين

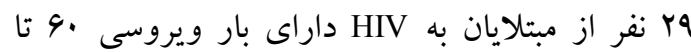
. بودند MAVYY. و و وجود فلور دهانى كانديدا (piral Load مشاهده نشد. ميزان سلول هاى CD4+C در اين گروه بين

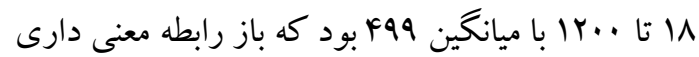
بين ميزان CD4+C و كلونيزاسيون كانديدايى (r p ) مشاهده نشد. تعداد צY نفر از اين بيماران حداقل روزى ليرى يككبار مسواكك مىزدند كه با كلونيزاسيون فلور كانديدايى(1) 
كر فته است همخو انى داشت(YV-YV). در مطالعه حاضر 99 \% از كانديداهاى ايزوله شده غير آلبيكنس بودند در حالى كه در كروه شاهد از ب كانديدا ايزوله شده VA آنها كانديدا آليكنس و تنها Y Y \% گ گونه هاى غير آلبيكنس بودند كه نشان دهنده يكك افزايش به سمت كونه هاى غير آليكنس در بيماران آلوده به HIV است و اين رويكرد نه تنها در مطالعات ديخر صورت گرفته در بيماران مبتلا به HIV وجود دارد، بلكه حتى در مطالعهاى كه Mohammadi و همكاران بر روى بيماران ديابتى انجام دادند نيز مشاهده شده است. بهطورى كه در مطالعه صورت گرفته بر روى بيماران ديابتى از بس گونه كانديداى جدا شده اب كونه آن آلبيكنس و 11 كونه آن غير آلبيكنس بوده در حالى كه در گروه كنترل آن مطالعه از IV كونه كانديداى جدا شده با كونه آن آلبيكنس و تنها \& گونه آن غير آلبيكنس بوده است(YV). هم:جنين در مطالعه حاضر كانديدا دابلينينسيس با فراوانى IV// ٪ از دهان بيماران جدا شد كه با مقدار به دست آمده توسط Khedri و

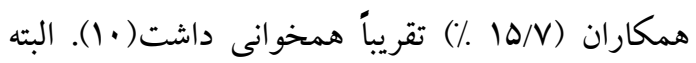
جداسازى كانديدا دابلينينسيس در ساير بيمارىهايى كه سيستم ايمنى بدن لزوماً تضعيف شده نيست ، نيز رو به افزايش است به طورى كه Kianipour و همكاران از • rا نمونه برنكو آلوئولار (BAL) دو كونه كانديدا دابلينينسيس و Abharian و همكاران در مطالعهاى كه If بر روى سم معتاد به مواد مخدر انجام داد، تعداد كونه كانديدا دابلينينسيس از دهان مبتلايان به مواد

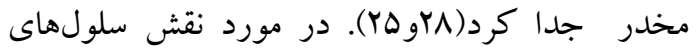
در كاهش كلونيز اسيون فلور كانديدايى اختلاف CD4+ نظر زياد وجود دارد كه بعضى براى آن رابطه معنى دار
كروه مبتلا به ديابت بودند و دهانشويه هم فقط توسط و نفر استفاده مىشد و اكثر اين افراد به سؤالات مربوط به نوع و ميزان رابطه جنسى ياسخ نداده بودند اين متغيرها در مطالعه مداخله داده نشدند.

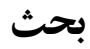
مطالعه حاضر نشان داد كه كلونيزاسيون كانديدا در دهان افراد مبتلا به ايدز در اصفهان بالاتر از افراد نرمال

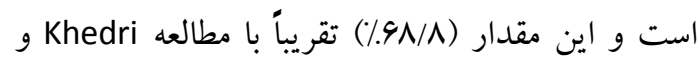
همكاران با ب/ه9.٪ Giuseppina و همكاران در ايتاليا با Kulshreshtha i.91/9 و همكاران در هند با سم/90\% و Lourenço و همكاران در برزيل با هـه\% همخوانى داشت(·rو r|-q). در عين حال اين مقدار در مقايسه با مقدارى كه Katiraee و همكاران در تهران به دست آوردند (YVV/\%) كمتر است(9)، كه شايد به اين علت باشد كه نمونه كيرى در مطالعه اخير در مركز تحقيقات ايدز تهران واقع در بيمارستان امام خمينى صورت كرفته كه مخصوص بيماران ايدزى است و ه9/9 \% آنها داراى علائم ظاهرى كانديديازيس دهانى بودهاند، در صورتى كه شركت كنند گان در اين مطالعه افراد HIV مثبت تحت درمان ضد ويروسى بوده كه هيج كدام داراى علائم كانديديازيس دهانى نبودند. در اين مطالعه فراوانترين كونه كانديدا جدا شده كانديدا آلبيكنس بود كه با ساير مطالعات همخوانى داشت و حتى در كروههاى در معرض خطر ديخر مثل افراد همودياليزى با 94/9 ٪6 افراد مبتلا به آسم كه كورتيكواستروئيد

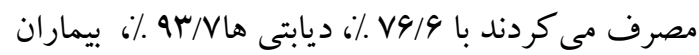

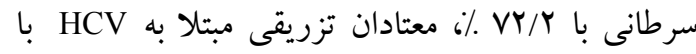
ه9/9 \% و ساير بيمارىهاى نقص سيستم ايمنى انجام 
نمودن بيوفيلم كانديدايى و مخمرها از دندانها و لثه و

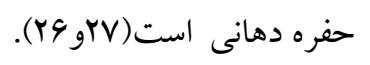

\section{نتيجه كيرى}

اين بررسى نشان داد كه ميزان جداسازى گونههاى

كانديدا به خصوص گُونه هاى غير آلبيكنس در افراد

مبتلا به HIV بيشتر از افراد سالم است و با توجه به

حساسيت اين گروه به عفونت هاى فرصت طلب از

جمله كانديديازيس، مانيتورينگك مرتب و دورهاى درو

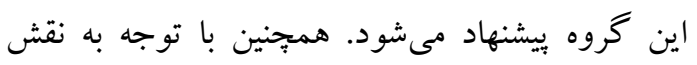

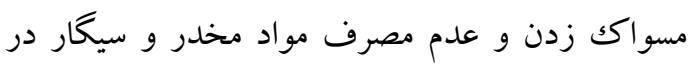

كاهش فلور كانديدايى، توصيه به رعايت بهداشت

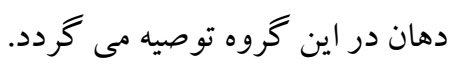

\section{تشكر و قدردانى}

مقاله حاضر حاصل بايان نامه كارشناسى ارشد با شماره

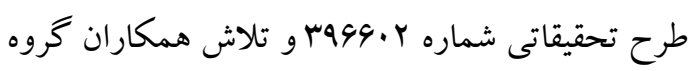

قارج و انگل شناسى دانشكده يزشكى اصفهان و مركز

بهداشت دانشگاه علوم يزشكى اصفهان است كه از

همكارى كليه اين عزيزان تقدير و تشكر به عمل بهل

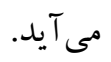

به دست آوردهاند( •rو •اوץr) و در مواردى رابطه معنى

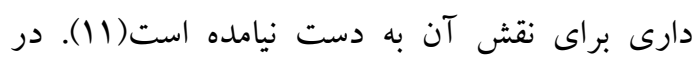

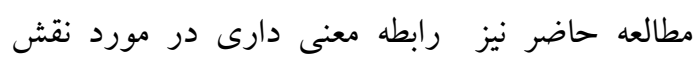
سلولهاى CD4+ و كاهش كلونيزاسيون كانديدايى به دست نيامد. در خصوص تأثير متغير مدت زمان ابتلا به ايدز و كلونيزاسيون فلور كانديدايى در اين مطالعه رابطه معنى دارى به دست نيامد درحالى كه در مطالعه

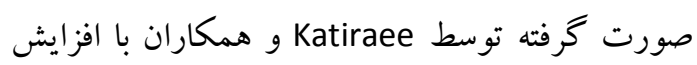
سن رابطه معنىدار وجود داشت، شايد علت اين تفاوت به اين دليل باشد كه بيشتر بيماران مطالعه حاضر مدت ردات ابتلايشان به HIV زير F مال بوده است(9). ميزان

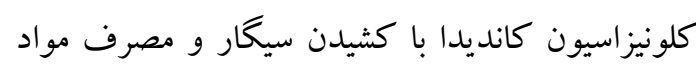
مخدر رابطه مستقيم داشت و تأثير مستقيم سيگار در

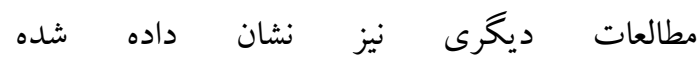

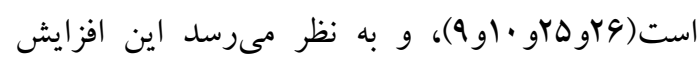
كلونيزاسيون كانديدا ناشى از تأثير سيگار در تغيير

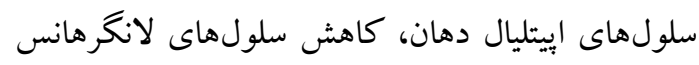
و لكوسيت هاى دهان باشد. همجنين رابطه معكوسى دهان

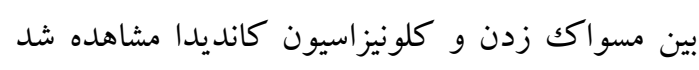
كه در مطالعات ديخر نيز اين رابطه به دست آمده است

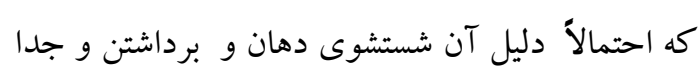

\section{Reference}

1. Malcolm D. Richardson DWW. Fungal Infection DIAGNOSIS AND MANAGEMENT2012.

2. Schwarcz L, Chen M-J, Vittinghoff E, Hsu L, Schwarcz S. Declining incidence of AIDSdefining opportunistic illnesses: results from 16 years of population-based AIDS surveillance. Aids. 2013;27(4):597-605.

3. Sangeorzan JA, Bradley SF, He X, Zarins LT, Ridenour GL, Tiballi RN, et al. Epidemiology of oral candidiasis in HIV-infected patients: colonization, infection, treatment, and emergence of fluconazole resistance. The American journal of medicine. 1994;97(4):33946.

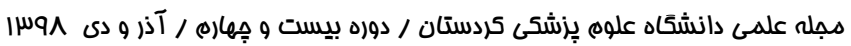


4. Strollo S, Lionakis MS, Adjemian J, Steiner CA, Prevots DR. Epidemiology of Hospitalizations Associated with Invasive Candidiasis, United States, 2002-2012(1). Emerg Infect Dis. 2016;23(1):7-13.

5. Pfaller M ,Diekema D. Epidemiology of invasive candidiasis: a persistent public health problem. Clinical microbiology reviews. 2007;20(1):133-63.

6. Akpan A, Morgan R. Oral candidiasis. Postgraduate medical journal. 2002;78(922):455-9.

7. Williams D, Lewis M. Pathogenesis and treatment of oral candidosis. Journal of oral microbiology. 2011;3(1):5771.

8.Coleman DC, Sullivan DJ, Bennett DE, Moran GP, Barry HJ, Shanley DB. Candidiasis: the emergence of a novel species, Candida dubliniensis. Aids. 1997;11(5):557-67.

9. Katiraee F KAR, Khalaj V, Hajiabdolbaghi M, Khaksar A A, Rasoulinejad M et al Oral candidiasis in Human Immunodeficiency Virus (HIV) infected Tehran Univ Med J. 2010;68 (1) $37-44$.

10. Khedri S, Santos A, Roudbary M, Hadighi R, Falahati M, Farahyar S, et al. Iranian HIV/AIDS patients with oropharyngeal candidiasis: identification, prevalence and antifungal susceptibility of Candida species. Letters in applied microbiology. 2018;67(4):392-9.

11. Campisi G, Pizzo G, Milici ME, Mancuso S, Margiotta V. Candidal carriage in the oral cavity of human immunodeficiency virus-infected subjects. Oral Surgery, Oral Medicine, Oral Pathology, Oral Radiology, and Endodontology. 2002;93(3):281-6.

12. Kulshreshtha S, Verma U, Khatri PK, Lal P. Prevalence of Oral Candida Carriage Rate among HIV Infected Asymptomatic and Non Infected Persons, their Antimycotic Sensitivity and its Association with CD4 Counts. International Journal of Current Microbiology and Applied Sciences. 2016;5(11):542-5.

13. Samiei S TK, Abasian L, mohrez M, Namdari H. HIV treatment counseling and diagnostic Country guidelines. In: Health Mo, editor. Department of Health and Medical Education2017.

14. Silva GAd, Bernardi TL, Schaker PDC, Menegotto M, Valente P. Rapid yeast DNA extraction by boiling and freeze-thawing without using chemical reagents and DNA purification. Brazilian Archives of Biology and technology. 2012;55(2):319-27.

15. Afsarian MH ZF, Kordbacheh P, Mahmoudi M, Rezaii S, Safara M. Identification and study of non-albicans candida species which isolated from clinical materials of patients with candidiasis. Tehran University Medical Journal (TUMJ). 2007;64:38-47.

16. Mohammadi R, Mirhendi H, Rezaei-Matehkolaei A, Ghahri M, Shidfar MR, Jalalizand N, et al. Molecular identification and distribution profile of Candida species isolated from Iranian patients. Medical mycology. 2013;51(6):657-63.

17. Ahmad S, Khan Z, Asadzadeh M, Theyyathel A, Chandy R. Performance comparison of phenotypic and molecular methods for detection and differentiation of Candida albicans and Candida dubliniensis. BMC infectious diseases. 2012;12(1):230.

18. Sampath A, Weerasekera M, Dilhari A, Gunasekara C, Bulugahapitiya U, Fernando N, et al. Comparison of duplex PCR and phenotypic analysis in differentiating Candida dubliniensis from Candida albicans from oral samples. AMB Express. 2017;7(1):141.

19. Pinjon E, Sullivan D, Salkin I, Shanley D, Coleman D. Simple, Inexpensive, Reliable Method for Differentiation of Candida dubliniensis fromCandida albicans. Journal of clinical microbiology. 1998;36(7):2093-5. 
20. Lourenço AG, Ribeiro AE, Nakao C, Motta AC, Antonio LG, Machado AA, Komesu MC. Oral Candida spp carriage and periodontal diseases in HIV-infected patients in Ribeirão Preto, Brazil. Revista do Instituto de Medicina Tropical de São Paulo. 2017;59.

21. Babaee, N, MirSaeed SA, Mohammadi GH, Sefidgar SAA, RahmaniI,SMM. Comporative evaluation of oral candida flora status in patients hemodyalisis and those with stage 3 and 4 chronic kidney disaease (2016): 199-208.

22. Azizi A IE, Rafiee A., Lawaf Sh ,Keykha N. The Prevalence of Candida Species in Saliva of Asthmatic Patients Treated with Inhaled Corticosteroids: Comparison of Beclomethasone and Fluticasone. Journal Of Dentistry. 2007;2:56-63.

23. Zakavi F, Shokohi T, Mofarrah R, Taghizadeh M, Hedayati MT. Identification of Different Species of Candida in Diabetic Patients using PCR-RFLP. Journal of Mazandaran University of Medical Sciences. 2015;25(128):1-9.

24. Maheronnaghsh M, Tolouei S, Dehghan P, Chadeganipour M, Yazdi M. Identification of Candida species in patients with oral lesion undergoing chemotherapy along with minimum inhibitory concentration to fluconazole. Advanced biomedical research. 2016;5.

25. Abharian PH, Dehghan P, Abharian PH, Tolouei S. Molecular characterization of Candida dubliniensis and Candida albicans in the oral cavity of drug abusers using duplex polymerase chain reaction. Current medical mycology. 2018;4(1):12.

26. Javaheri MR, Mohammadi F, Chadeganipour M, Nekoian S, Dehghan P. Identification of Candida species in oral cavity of smokers and nonsmokers. Journal of Isfahan Medical School. 2016;33(362):2105-10.

27.Mohammadi F, Javaheri MR, Nekoeian S, Dehghan P. Identification of Candida species in the oral cavity of diabetic patients. Current medical mycology. 2016;2(2):1.

28. Kianipour S, Ardestani ME, Dehghan P. Kianipour S, Ardestani ME, Dehghan P. Identification of Candida albicans and Candida dubliniensis species isolated from bronchoalveolar lavage samples using genotypic and phenotypic methods. Advanced biomedical research. 2018;7.

29. Sun H, Chen Y, Zou X, Li H, Yin X, Qin H, et al. Occurrence of oral Candida colonization and its risk factors among patients with malignancies in China. Clinical oral investigations. 2016;20(3):459-67.

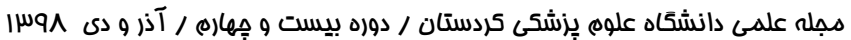

